\title{
Pelatihan Pembuatan Puding Cokelat Lapis Daun Kelor Sebagai Hidangan Penutup (Dessert) Yang Sehat
}

\author{
The training for making Moringa leaf-coated chocolate pudding as a healthy dessert
}

\author{
Yuli Febrianti ${ }^{1 *}$, Reny Dwi Riastuti ${ }^{2}$, Fitria Lestari ${ }^{3}$ Juwati $^{4}$ \\ ${ }^{1,2,3}$ Program Studi Pendidikan Biologi, Jurusan MIPA, STKIP-PGRI Lubuklinggau, Indonesia \\ ${ }^{4}$ Program Studi Pendidikan Bahasa dan Sastra Indonesia, Jurusan Bahasa dan Seni, STKIP-PGRI \\ Lubuklinggau, Indonesia \\ e-mail: ${ }^{1} y u l i \_f e b r i . a n t i 16 @ y a h o o . c o . i d,{ }^{2}$ renydwiriastuti09@gmail.com, ${ }^{3}$ Fitrinq@gmail.com, \\ ${ }^{4}$ watiaja56@ymail.com
}

\begin{abstract}
Abstrak
Daun Kelor dapat dijadikan sebagai bahan makanan (pangan) fungsional. Pemanfaatan kelor sebagai bahan makanan hanya terbatas untuk diolah menjadi sayuran saja yang dapat membosankan bila terlalu sering dikonsumsi. hanya beberapa orang saja yang mau memanfaatkan tanaman Kelor sebagai bahan pangan fungsional. Warga masyarakat sebetulnya sudah memanfaatkan lahan kosong di lingkungan rumahnya masing-masing untuk dimanfaatkan sebagai tanaman sayuran melalui polybag, namun hanya untuk jenis tanaman tertentu saja, sementara tanaman Kelor belum menjadi perhatian dan hanya dianggap sebagai tanaman pagar yang kurang dimanfaatkan sebagai tanaman pangan. Kegiatan pelatihan pembuatan puding cokelat lapis daun Kelor sebagai hidangan penutup (dessert) yang sehat ini untuk meningkatkan ketahanan pangan warga masyarakat sehingga tetap sehat, pendapatan keluarga bertambah, dan ekonomi masyarakat setempat akan meningkat, menjadikan warga masyarakat lebih sejahtera, terutama di masa sekarang dengan biaya kebutuhan hidup semakin meningkat tajam khususny RT 05 Kecamatan Kampung Melayu Kota Bengkulu. Sasaran peserta pelatihan yaitu warga masyarakat sebanyak 27 orang dan teknik pengumpulan data melalui observasi dengan menggunakan lembar observasi. Peserta pelatihan telah mengalami peningkatan keterampilan secara bermakna yaitu dari 58,33 (keterampilan awal) menjadi 91,67 (keterampilan akhir). Hal ini terbukti dari kesungguhan warga masyarakat yang ditunjukkan dalam partisipasi yang sangat baik pada saat pelatihan.
\end{abstract}

Kata kunci: Puding, daun Kelor, Dessert.

\begin{abstract}
Moringa leaves can be used as a functional food ingredient. The use of Moringa as a food ingredient is only limited to be processed into vegetable dishes which can be boring if consumed too often. only a few people are willing to use the Moringa plant as a functional food ingredient. People in the community actually have used the empty land in their respective homes to be used as vegetable crops through polybags, but only for certain types of plants, while the Moringa plant has not become a concern and is only considered a hedge plant that is not used as a food crop. The training activity for making Moringa leaf-coated chocolate pudding as a healthy dessert is to increase the food security of the community so that it remains healthy, increases family income, and the local community's economy will improve, making community members more prosperous, especially in the present at a cost. the need for life is increasing sharply, especially RT 05 Kampung Melayu Sub-district, Bengkulu City. The target of the training participants is the community as many as 27 people and data collection techniques through observation using observation sheets. The training participants have experienced a significant increase in skills, namely from 58,33 (initial skills) to 91,67 (final skills). This is evident from the seriousness of the community members who were shown in excellent participation during the training.
\end{abstract}

Keyword: Pudding, Moringa leaves, Dessert.

\section{PENDAHULUAN}

Kelor merupakan tanaman perdu dengan ketinggian 7-11 meter dan tumbuh subur mulai dari dataran rendah sampai ketinggian 700 meter diatas permukaan laut (Mendieta-Araica, dkk., 2013, p. 81). Daun kelor memiliki kandungan gizi yang tinggi dan mudah didapatkan (Ariani, dkk., 2013). Daun Kelor (Moringa oleifera) kaya akan mineral, vitamin dan kandungan

Submitted: Januari 2021, Accepted: Januari 2021, Published: Februari 2021

ISSN 2746-6345 (media online) 
fitokimia. Ekstrak daun Kelor banyak digunakan dalam berbagai percobaan di bidang mal nutrisi, memperlancar ASI. Selain itu, berpotensi sebagai antioksidan, anti kanker, anti inflammatory, anti diabet dan anti mikroba. Penelitian sebelumnya melaporkan bahwa dari bagian-bagian tanaman Kelor, kandungan nutrisi dan fitokimia terbaik adalah pada daun Kelor (Gopalakrishnan, Doriya and Kumar, 2016, p. 49).

Daun kelor (Moringa oleifera) memiliki fungsi yang sangat baik terhadap kesehatan seperti anti-hipertensi, antikanker dan antimikroba (Evivie et al., 2015, p. 649; Leone et al., 2015, p. 18923). Hasil analisis Laboratorium Politani Negeri Payakumbuh 2019, menunjukkan bahwa daun Kelor mengandung antioksidan, flavonoid dan saponin, sehingga bermanfaat untuk kesehatan dan menurunkan kolesterol bahan pangan yang menggunakannya (Suhaemi, dkk., 2019, p. 177). Daun Kelor merupakan bahan makanan segar sehingga cepat mengalami kerusakan (Suarni, 2008, p. 145). Selain dikonsumsi langsung dalam bentuk segar, kelor juga dapat diolah menjadi bentuk tepung atau powder yang dapat digunakan sebagai fortifikan untuk mencukupi nutrisi (Kurniawati, dkk., 2018, p. 238). Tanaman Kelor berpotensi sebagai penghasil pangan seperti sayur bening, ongseng bacem, polong, teh, keripik dan lain-lain. Sebagi obat tradisional meliputi obat segala penyakit lambung, kolesterol, asam urat, kencing manis, darah tinggi, kanker, kolesterol. Sebagai ritual adat meliputi santet, pengusir roh, penghilang pengasihan, pemandian mayat, dan kesurupan. Selain itu, untuk pembibitan, tanaman pagar untuk pembatas rumah,dan untuk kayu bakar. Pemanfaatan Kelor tertinggi adalah untuk pangan (Dani, dkk., 2019, p. 51).

Salah satu bahan pangan yang berpotensi untuk dijadikan sebagai makanan pembawa dalam upaya fortifikasi zat besi di Indonesia yaitu daun kelor. Terdapat banyak kandungan nutrisi pada daun Kelor, sayangnya masyarakat setempat tidak memanfaatkannya secara maksimal (Hasanah, dkk., 2019, p. 44). Pemanfaatan daun Kelor sampai saat ini masih sangat kurang/belum banyak diketahui, pada umumnya hanya dikenal sebagai salah satu menu sayuran (Kurniawati, 2018, p. 243). Masyarakat umumnya hanya memanfaatkan daun Kelor sebagai makanan yang diolah menjadi sayur bening. Oleh karena itu, diversifikasi pengolahan pangan perlu diterapkan yang bertujuan untuk meningkatkan kandungan gizi serta nilai tambah dari komoditas pangan agar lebih berdaya guna bagi kebutuhan manusia (Ariani, dkk., 2013).

Berdasarkan hasil observasi yang dilakukan pada 29 Oktober 2020 diketahui bahwa warga masyarakat di RT 05 Kecamatan Kampung Melayu tidak mengetahui bahwa daun Kelor dapat dijadikan sebagai bahan makanan (pangan) fungsional. Adapun untuk memperoleh informasi tentang pemilihan bahan, perancangan kemasan, perancangan logo dan praktik pembuatan puding cokelat lapis daun Kelor sebagai hidangan penutup (dessert) yang sehat yaitu Ariani, dkk., (2013), Dani, dkk., (2019, p. 44-52), Evivie et al., (2015, 649-656), Leone et al., (2015), Gopalakrishnan, Doriya and Kumar (2016), Hariyanto dan Jupriyono, (2017, p. 24-26), Hasanah, dkk., (2019, p. 41-45), Kurniawati (2018, p. 238-243), Mendieta-Araica, dkk., (2013, p. 81-92), Suarni (2008, p. 145-151), Suhaemi, dkk., (2019, p. 177-184), Sasha (2019), Widjaja, dkk., (2015).

Fakta dilapangan menunjukkan bahwa pemanfaatan kelor sebagai bahan makanan hanya terbatas untuk diolah menjadi sayur bening saja yang dapat membosankan bila terlalu sering dikonsumsi. hanya beberapa orang saja yang mau memanfaatkan tanaman Kelor sebagai bahan pangan fungsional. Warga masyarakat di RT 05 Kecamatan Kampung melayu Kota Bengkulu sebetulnya sudah memanfaatkan lahan kosong di lingkungan rumahnya masing-masing untuk dimanfaatkan sebagai tanaman sayuran melalui polybag, namun hanya untuk jenis tanaman tertentu saja, sementara tanaman Kelor belum menjadi perhatian dan hanya dianggap sebagai tanaman pagar yang kurang dimanfaatkan sebagai tanaman pangan. Disamping itu berdasarkan hasil observasi, diketahui sebagian besar belum mengetahui bahwa tanaman Kelor mengandung gizi tinggi yang dapat diolah sebagai bahan pangan alternatif. Melihat permasalahan tersebut, maka perlu untuk dilakukan kegiatan Pengabdian Pada Masyarakat dalam bentuk pelatihan pembuatan puding cokelat lapis daun Kelor sebagai hidangan penutup (dessert) yang sehat untuk meningkatkan ketahanan pangan bagi masyarakat, khususnya di RT 05 Kecamatan Kampung Melayu Kota Bengkulu.

Pelatihan Pembuatan Puding Coklat Lapis Daun Kelor Sebagai Hidangan Penutup (Dessert) yang Sehat (Yuli Febrianti, Renny Dwi Riastuti, Fitria Lestari, Juwati) 
Tim Pengabdian melakukan diskusi dan konsultasi dengan ketua RT 05 agar menginformasikan kepada masyarakat bahwa ada kegiatan pelatihan pembuatan pudding cokelat lapis daun Kelor sebagai hidangan penutup (dessert) yang sehat. Pelatihan ini kedepannya diharapkan dapat menjadi peluang usaha di bidang kuliner pangan fungsional. Dengan adanya usaha tersebut, bisa mengajak warga masyarakat untuk melakukan pengelolaan tanaman Kelor yang hasilnya bisa dijual atau di konsumsi oleh masyarakat, sehingga tetap sehat, pendapatan keluarga bertambah, dan ekonomi masyarakat setempat akan meningkat, menjadikan warga masyarakat lebih sejahtera, terutama di masa sekarang dengan biaya kebutuhan hidup semakin meningkat tajam di RT 05 Kecamatan Kampung Melayu Kota Bengkulu. Adanya diskusi, konsultasi awal, dan koordinasi tim pengusul kepada pihak RT 05 ini diharapkan menjadi gerbang awal untuk mendukung dan memudahkan terlaksananya kegiatan pelatihan pembuatan pembuatan pudding cokelat lapis daun Kelor sebagai hidangan penutup (dessert) yang sehat. Dukungan yang ada berupa kemudahan tim pengusul dalam mengurus administrasi kepada semua pihak terkait, ketersediaan lokasi kegiatan pelatihan pembuatan pudding cokelat lapis daun Kelor sebagai hidangan penutup (dessert) yang sehat, dan mengajak serta meningkatkan antusiasme warga masyarakat untuk mengikuti kegiatan pelatihan pembuatan pudding cokelat lapis daun Kelor sebagai hidangan penutup (dessert) yang sehat yang diadakan oleh tim pengabdian.

\section{METODE PELAKSANAAN}

Sasaran kegiatan pelatihan pembuatan pudding cokelat lapis daun Kelor sebagai hidangan penutup (dessert) yang sehat adalah warga masyarakat yang ada di RT 05 Kecamatan Kampung Melayu Kota Bengkulu yaitu sebanyak 27 orang.

Narasumber dan materi dalam kegiatan pelatihan pembuatan pudding cokelat lapis daun Kelor sebagai hidangan penutup (dessert) yang sehat dapat dilihat pada Tabel 1 sebagai berikut:

Tabel 1. SUSUNAN TIM PENGABDIAN

\begin{tabular}{|c|c|c|c|c|c|}
\hline No & Nama/NIDN & Instansi Asal & Bidang Ilmu & $\begin{array}{c}\text { Alokasi } \\
\text { Waktu } \\
\text { (Jam/Minggu) } \\
\end{array}$ & Uraian Tugas \\
\hline 1. & $\begin{array}{l}\text { Reny Dwi Riastuti, } \\
\text { M.Pd.Si/0204098801 }\end{array}$ & $\begin{array}{l}\text { STKIP PGRI } \\
\text { Lubuklinggau }\end{array}$ & Pendidikan Biologi & $32 \mathrm{Jam}$ & $\begin{array}{c}\text { Pemilihan daun } \\
\text { Kelor untuk } \\
\text { pembuatan } \\
\text { puding cokelat lapis } \\
\text { daun Kelor }\end{array}$ \\
\hline 2 & $\begin{array}{c}\text { Juwati, } \\
\text { M.Pd./0215068604 }\end{array}$ & $\begin{array}{c}\text { STKIP PGRI } \\
\text { Lubuklinggau }\end{array}$ & Pendidikan Biologi & $32 \mathrm{Jam}$ & $\begin{array}{c}\text { Cara merancang } \\
\text { kemasan puding } \\
\text { cokelat lapis daun } \\
\text { Kelor } \\
\end{array}$ \\
\hline 3 & $\begin{array}{l}\text { Fitria Lestari, } \\
\text { M.Pd./0220039001 }\end{array}$ & $\begin{array}{l}\text { STKIP PGRI } \\
\text { Lubuklinggau }\end{array}$ & Pendidikan Biologi & $32 \mathrm{Jam}$ & $\begin{array}{l}\text { Cara merancang logo } \\
\text { untuk kemasan } \\
\text { puding cokelat lapis } \\
\text { daun Kelor }\end{array}$ \\
\hline 4. & $\begin{array}{c}\text { Yuli Febrianti, } \\
\text { M.Pd.Si/0216029002 }\end{array}$ & $\begin{array}{l}\text { STKIP PGRI } \\
\text { Lubuklinggau }\end{array}$ & Pendidikan Biologi & $32 \mathrm{Jam}$ & $\begin{array}{l}\text { Praktik pembuatan } \\
\text { puding cokelat lapis } \\
\text { daun Kelor }\end{array}$ \\
\hline
\end{tabular}

Adapun Tahap pelatihan yang dilakukan tim dapat dilihat pada Tabel 2 sebagai berikut:

Tabel 2. TAHAP PELATIHAN KEGIATAN

\begin{tabular}{lcc}
\hline No & Tahap Pelatihan & Tujuan yang Dicapai \\
\hline 1 & Tim melakukan penyampaian materi mengenai & Mitra dapat mengetahui pemilihan daun Kelor, perancangan kemasan, \\
& pemilihan daun Kelor, perancangan kemasan, & perancangan logo untuk pembuatan puding cokelat lapis daun Kelor \\
& perancangan logo untuk pembuatan puding & \\
\hline
\end{tabular}




\begin{tabular}{ll}
\hline \multicolumn{3}{l}{ cokelat lapis daun Kelor } \\
\hline 2 Tim memberikan bantuan peralatan & Mitra dapat dengan mudah mempraktikkan pembuatan puding cokelat \\
(loyang/cetakan aluminium segi empat, lapis daun Kelor sebagai hidangan penutup (dessert) yang sehat \\
saringan, nampan, spatula plastik/sendok kue, \\
panci, centong sendok stainless steel, mixer, \\
timbangan jarum plastik, blender, kompor) \\
yang akan digunakan untuk pembuatan sari \\
daun Kelor, pembuatan puding cokelat, \\
pembuatan puding daun Kelor, pengemasan \\
Tim melakukan pelatihan tentang cara Peserta pelatihan mampu memahami cara pembuatan sari daun Kelor, \\
pembuatan sari daun Kelor, pembuatan puding pembuatan puding cokelat, pembuatan puding daun Kelor, pengemasan \\
cokelat, pembuatan puding daun Kelor, \\
pengemasan \\
Tim melakukan praktik pembuatan puding Peserta pelatihan mampu mempraktikkan pembuatan puding cokelat \\
cokelat lapis daun Kelor sebagai hidangan lapis daun Kelor sebagai hidangan penutup (dessert) yang sehat \\
penutup (dessert) yang sehat
\end{tabular}

Adapun Jadwal kegiatan yang akan dilakukan dapat dilihat pada Tabel 3 sebagai berikut:

Tabel 3. JADWAL KEGIATAN PPM

\begin{tabular}{|c|c|c|c|c|c|c|c|c|c|c|c|}
\hline \multirow{2}{*}{ No } & \multirow{2}{*}{ Jenis Kegiatan } & \multicolumn{10}{|c|}{ Nopember } \\
\hline & & 18 & 19 & 20 & 21 & 22 & 23 & 24 & 25 & 26 & 27 \\
\hline 1 & $\begin{array}{lcc}\text { Persiapan } & \text { (survey } & \text { awal, } \\
\text { administrasi } & \text { dan koordinasi) }\end{array}$ & $\mathrm{x}$ & & & & & & & & & \\
\hline 2 & Persiapan kegiatan lapangan & & $\mathrm{x}$ & & & & & & & & \\
\hline \multirow[t]{3}{*}{3} & $\begin{array}{l}\text { Pemberian materi tentang pemilihan } \\
\text { daun Kelor untuk pembuatan } \\
\text { puding cokelat lapis daun Kelor }\end{array}$ & & $\mathrm{x}$ & & & & & & & & \\
\hline & $\begin{array}{l}\text { Pemberian materi tentang cara } \\
\text { merancang kemasan puding cokelat } \\
\text { lapis daun Kelor }\end{array}$ & & & $\mathrm{x}$ & & & & & & & \\
\hline & $\begin{array}{l}\text { Pemberian materi tentang cara } \\
\text { merancang logo untuk kemasan } \\
\text { puding cokelat lapis daun Kelor }\end{array}$ & & & $\mathrm{x}$ & & & & & & & \\
\hline 4 & $\begin{array}{l}\text { Praktik pembuatan puding cokelat } \\
\text { lapis daun Kelor }\end{array}$ & & & & $\mathrm{x}$ & & & & & & \\
\hline 5 & Monitoring dan Evaluasi & & & & & $\mathrm{x}$ & $\mathrm{X}$ & $\mathrm{x}$ & & & \\
\hline 6 & Pengolahan data & & & & & & & & $\mathrm{x}$ & $\mathrm{x}$ & $\mathrm{x}$ \\
\hline 7 & Pembuatan laporan & & & & & & & & $\mathrm{x}$ & $\mathrm{x}$ & $\mathrm{x}$ \\
\hline
\end{tabular}

Adapun teknik pengumpulan data melalui observasi dengan menggunakan lembar observasi yang dapat dilihat pada Tabel 4 sebagai berikut:

Tabel 4. LEMBAR PENGAMATAN KETERAMPILAN

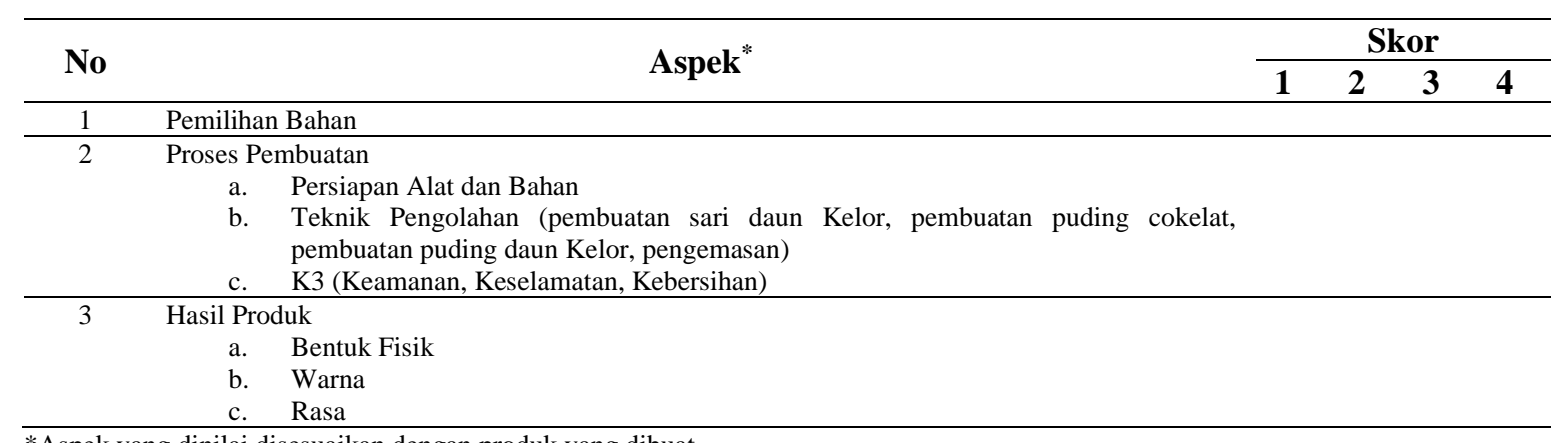

*Aspek yang dinilai disesuaikan dengan produk yang dibuat

**Skor diberikan tergantung dari ketepatan dan kelengkapan jawaban yang diberikan semakin lengkap dan tepat jawaban, semakin tinggi perolehan skor 
Adapun teknik analisis data yaitu dengan desktiptif kualitatif yaitu dapat diperoleh dari rumus:

Nilai $=\frac{\text { Jumlah skor yang diperoleh }}{12} \times 100$

\section{HASIL DAN PEMBAHASAN}

Pada pelaksanaan kegiaatan Pengabdian Pada Masyarakat (PPM) tentang pelatihan pembuatan puding cokelat lapis daun Kelor sebagai hidangan penutup (dessert) yang sehat berlangsung selama tiga hari yaitu mulai dari tanggal 19 sampai dengan 21 Nopember 2020. Kegiatan ini mulai dari persiapan (survey awal, Administrasi, dan koordinasi), persiapan kegiatan lapangan, pemberan materi pelatihan, praktik puding cokelat lapis daun Kelor sebagai hidangan penutup (dessert) yang sehat dan monitoring serta evaluasi. Pada saat pelaksanaan kegiatan, Masyarakat diberikan materi pelatihan tentang Pemilihan Dasar Kelor, Perancangan Kemasan, Perancangan Logo Kemasan, dan Praktik pembuatan pudding cokelat lapis daun Kelor sebagai hidangan penutup (dessert) yang sehat. Total waktu yang dibutuhkan dalam penyampaian materi pelatihan tersebut sebanyak 32 jam dengan pemateri Dosen STKIP PGRI Lubuklinggau. Setelah Peserta pelatihan mendapatkan beberapa materi, selanjutnya dilakukan praktik. Minat warga masyarakat untuk mengikuti pelatihan sangat tinggi. Hal ini terlihat dengan banyaknya warga masyarakat yang hadir yaitu sebanyak 27 orang dan mengikuti pelatihan dengan sungguh-sungguh. Selain itu, pada saat dilakukan praktik pengolahan makanan berbahan dasar Kelor, seluruh warga masyarakat yang menjadi peserta dalam pelatihan dapat mengikuti kegiatan dengan antusias sampai semua kegiatan berakhir. Warga masyarakat mengalami peningkatan keterampilan dalam pembuatan puding cokelat lapis daun Kelor sebagai hidangan penutup (dessert) yang sehat yaitu dengan perolehan nilai seperti pada Gambar 1

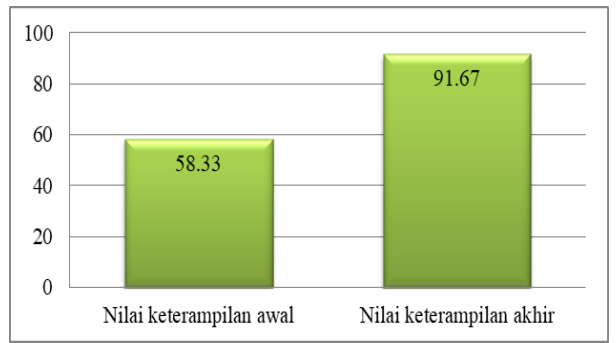

Gambar 1. HASIL NILAI KETERAMPILAN YANG DIPEROLEH WARGA MASYARAKAT DALAM PEMBUATAN PUDING COKELAT LAPIS DAUN KELOR SEBAGAI HIDANGAN PENUTUP (DESSERT) YANG SEHAT

Pada saat kegiatan praktik pembuatan puding cokelat lapis daun Kelor sebagai hidangan penutup (dessert) yang sehat terdapat peningkatan keterampilan warga masyarakat melalui pengamatan observasi dalam hal pemilihan bahan, proses pembuatan, dan hasil produk yaitu dari 58,33 (nilai keterampilan awal) menjadi 91,67 (nilai keterampilan akhir). Seluruh warga masyarakat sebagai peserta pelatihan dapat membuat aneka olahan daun Kelor serta melakukan pengemasan berlogo dengan baik. Produk puding cokelat lapis daun Kelor daun yang dihasilkan pada pelatihan sangat menarik dan dapat dikembangkan. Selain itu kegiatan yang dilakukan terdapat interaksi yang sangat bermanfaat bagi warga masyarakat untuk meningkatkan ketahanan pangan untuk dikomersialkan. Hal ini sesuai dengan Hasanah, dkk., (2019, p. 44) yaitu seluruh mitra kerja dapat membuat aneka olahan daun Kelor yang menarik, melakukan pengemasan dengan baik dan dapat dikembangkan serta sangat bermanfaat bagi mitra kerja. Menurut Dani, dkk., (2019, p.51) menyatakan bahwa terdapat interaksi antara masyarakat desa Kedungbulus Gembong Pati dengan tumbuhan Kelor. Selain itu, menurut Hariyanto, dkk., 2017, p. 44) menyatakan bahwa pemanfaatan Kelor sebagai bentuk usaha untuk meningkatkan 
ketahanan pangan, salah satunya masyarakat perlu diberikan pelatihan pemanfaatan Kelor. Peserta pelatihan juga telah mampu memproduksi beberapa jenis makanan olahan Kelor untuk dikomersialkan meski baru terbatas.

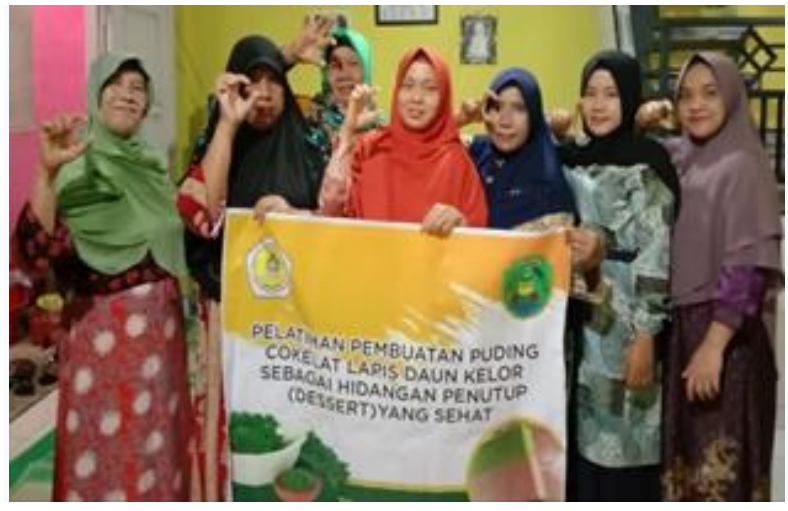

Gambar 2. FOTO BERSAMA PESERTA PELATIHAN PEMBUATAN PUDING COKLAT LAPIS DAUN KELOR SEBAGAI HIDANGAN PENUTUP YANG SEHAT

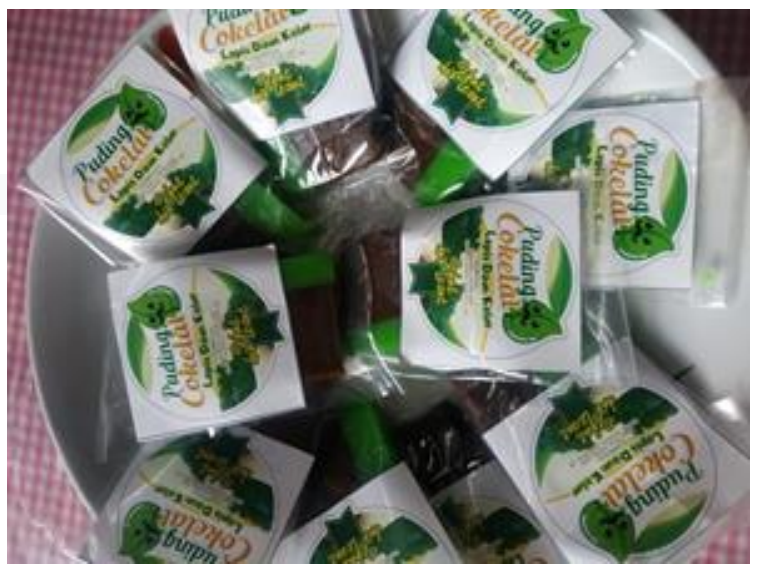

Gambar 3. PRODUK PUDING COKELAT LAPIS DAUN KELOR

\section{KESIMPULAN}

Berdasarkan kegiatan pengabdian pada masyarakat (PPM) melalui pelatihan pembuatan puding cokelat lapis daun Kelor sebagai hidangan penutup (dessert) yang sehat tersebut dapat disimpulkan bahwa, Warga Masyarakat RT 05 Kecamatan Kampung Melayu Kota Bengkulu mengalami peningkatan keterampilan yaitu dari 58,33 (keterampilan awal) menjadi 91,67 (keterampilan akhir). Hal ini terbukti dari kesungguhan warga masyarakat yang ditunjukkan dalam mengikuti pelatihan. Indikator ini dapat dilihat dari meningkatnya keterampilan secara bermakna setelah mengikuti Pelatihan. Disamping itu juga dapat dilihat dari partisipasi yang sangat baik pada saat praktik pembuatan puding cokelat lapis daun Kelor sebagai hidangan penutup (dessert) yang sehat. 


\section{DAFTAR PUSTAKA}

Ariani, M., Hermanto., Hardono, G, S., Sugiarto., Wahyudi, T.S. (2013). Kajian Strategi Pengembangan Diversifikasi Pangan Lokal. Bogor: Badan Penelitian dan Pengembangan Pertanian. http://pse.litbang.pertanian.go.id

Dani, B.Y.D., Wahidah. B.F., dan Syaifudin, A. (2019). Etnobotani Tanaman Kelor (Moringa oleifera Lam.) di Desa Kedungbulus Gembong Pati. Al-Hayat: Journal of Biology and Applied Biology, 2(2): 44-52. Doi: 10.21580/ah.v2i2.4659

Evivie, S. E., Ebabhamiegbebho, P. A., Imaren, J., and Igene, J. (2015). Evaluating the organoleptic properties of soy meatballs (beef) with varying levels of Moringa oleifera leaf powder. Journal of Applied Science and Environmental Management . 19(4): 649-656. Doi: 10.4314/jasem.v19i4.12

Gopalakrishnan, L., Doriya, K., and Kumar, D. S. (2016). Moringa oleifera: A review on nutritive importance and its medicinal application. Food Science and Human Wellness, 5:49-56. https://doi.org/10.1016/j.fshw.2016.04.001

Hariyanto, T dan Jupriyono. (2017). Peningkatan Kemampuan Masyarakat Dalam Pengembangan Pangan Berbahan Dasar Tanaman Kelor Di RW 8 Kelurahan Bareng Kota Malang. Jurnal Idaman, 1(1):24-26. https//doi.org/10.31290/j.idaman.v(1)i(1)y(2017).page:24-26

Hasanah, M., Fitriana, E.R., dan Indriati, N., Masruroh, S., Sulastri, Novia, C. (2019). Pemberdayaan Masyarakat Melalui Diversifikasi Olahan Daun Kelor. Jurnal Teknologi Pangan, 10(1):41-45. https//doi.org/10.35891/tp.v10i1.1477

Kurniawati, I., Fitriyya, M., dan Wijayanti. (2018). Karakteristik Tepung Daun Kelor Dengan Metode Pengeringan Sinar Matahari. Prosiding Seminar Nasional Unimus, 1:238-243.

Leone, A., Fiorillo, G., Criscuoli, F., Ravasenghu, S., Santagostini, L., Fico, G., Spadafranca, A., Battezzati, A., Schiraldi, A., Pozzi, F., di Lello, S., Filippini, S. and Bertoli, A. (2015). Nutritional characterization and phenolic profiling of Moringa oleifera leaves grown in Chad, Sahrawi Refugee Camps, and Haiti. International Journal of Molecular Sciences, 16(8):18923-18937.

Mendieta-Araica, B., Sporndly, E., Reyes-Sanchez, N., Salmeron-Miranda, F., Halling, M. (2013). Biomass production and chemical composition of Moringa oleifera under differentplanting densities and plefels of nitrogen fertilization. Agroforestry System, 87(1):81-92. Doi: 10.1007/s10457-012-9525-5

Sasha. (2019). Puding Karakter Kemasan Plastik Gelas Jadi Usaha dengan Pemasukan Menguntungkan!. https://dikemas.com/puding-karakter-gelas-plastik-menguntungkan.

Suarni. (2008). Pemanfaatan tepung sorgum untuk produk olahan. Jurnal Litbang Pertanian. 23(4):145-151.

Suhaemi, Z., Syahrial, Martadona, I., Dianti, D., Rahmawati, Y., Elhakim, S.K., Nurlina. (2019). Aplikasi Teknologi Berbasis Daun Kelor (Moringa Oleifera) Guna Meningkatkan Nilai Ekonomis Lahan. Jurnal Hilirisasi IPTEKS, 2(3a): 177-184. https://doi.org/10.25077/jhi.v2i3.a.240

Widjaja, D.C., Bramantya, B., \& Sutanto, R.P. (2015). Perancangan Kemasan Produk Purro Puding. https://media.neliti.com/media/publications/86965-ID-perancangan-kemasan-nonniepudding-sebag.pdf. 